\title{
ILMENORUTILE AND STRÜVERITE FROM PENIKOJA, SOMERO, SW FINLAND
}

\author{
JaAkko Sirvola \\ Geological Survey of Finland, Otaniemi, Finland
}

\begin{abstract}
This paper reports the occurrence of ilmenorutile (niobian rutile) and strüverite (tantalian rutile) in two specimens from the Penikoja pegmatite in Somero, SW Finland. One of the specimens contains strüverite as inclusions in pseudoixiolite, whereas the other specimen shows both ilmenorutile and strüverite in association with columbite. Microprobe analyses of the minerals concerned are presented.
\end{abstract}

\section{Introduction}

Several niobium and tantalum minerals from the Tammela-Somero pegmatite area in SW Finland have recently been described by Vorma (1965) and by Vorma and Siivola (1967). In conjunction with these studies a phase new to this pegmatite province was recorded. Subsequent examination of this phase proved it to represent partly ilmenorutile (niobian rutile) and partly strüverite (tantalian rutile). Because these two minerals have not previously been found in Finland and because they are in association with each other, their occurrence in the Penikoja pegmatite of the Somero commune will be reported in this paper.

\section{The specimens}

The following two specimens were available: Specimen No. 4561. University of Helsinki collection, labelled as Ainalite from Penikoja, Somero». The following minerals have been identified: Cassiterite with pseudo-ixiolite inclusions and pseudo-ixiolite with strüverite and tapiolite inclusions. The strüverite grains measure up to $60 \mu$ in length. Their shape is irregular and polishing hardness about the same as that of pseudo-ixiolite (Fig. 1). This sample, especially the pseudo-ixiolite phase, has formerly been studied by Vorma (1965).

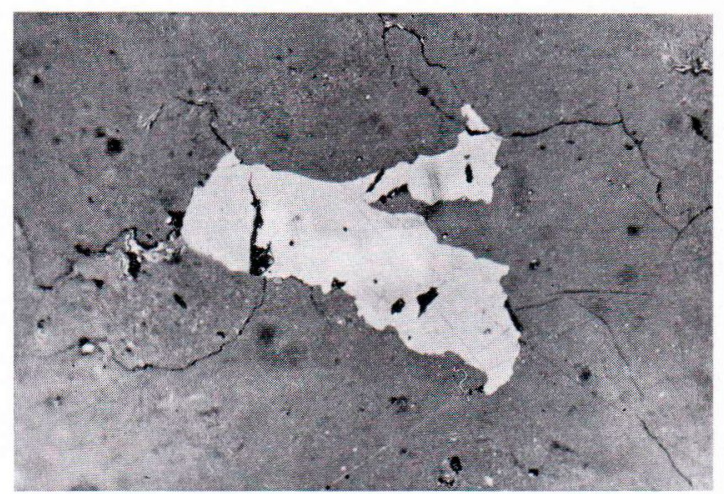

Fig. 1. Strüverite as an inclusion in pseudo-ixiolite. Nic. I. Magnification 1070 x. Photo Erkki Halme. 
Specimen No. 8810. Polished section collection of the Geological Survey of Finland, labelled as »Vorma -66, Penikoja, Somero». The specimen is a single crystal exhibiting the crystal form of rutile. The pyramidal faces (111) are well developed. A microscopic examination of the polished section in reflected light reveals the sample to consist of ilmenorutile and strüverite with some columbite as shown in Fig. 2. Small grains of cassiterite are also present. The columbite grains have uniform optical orientation in large areas of the microscope field of view. This fact probably indicates that the texture is caused by exolution of columbite.

The optical properties of the ilmenorutile and strüverite studied are similar to each other showing a light creamy colour, weak bireflectivity and moderate anisotropy. Columbite and pseudoixiolite are brownish in colour and show more intense bireflectivity.

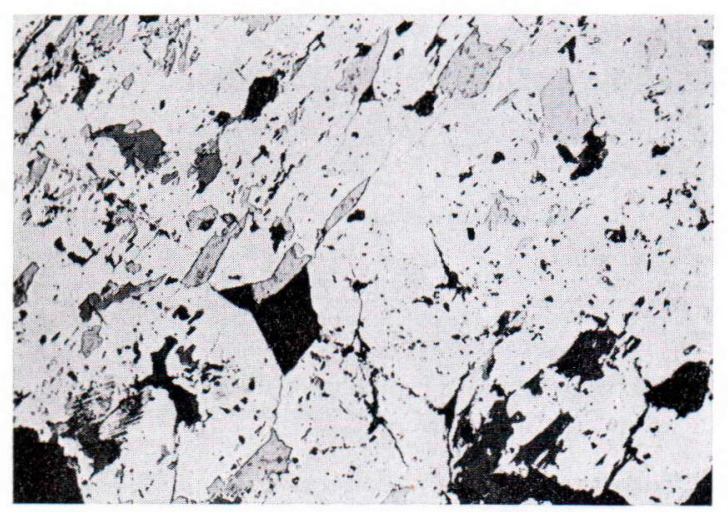

Fig. 2. Ilmenorutile-strüverite (white) with columbite (grey). Black areas are silicate minerals. Nic. ||. Magnification 220 x. Photo Erkki Halme.

\section{Chemical composition}

The chemical analyses (Tables 1 and 2) were performed by using an electron microprobe, model »Geoscan». Normally the analysing conditions were as follows: Accelerating voltage 25 $\mathrm{kV}$, specimen current $60 \mathrm{~m} \mu \mathrm{A}$ with probe diameter of approximately $1 \mu$. Sometimes an accel-
TABLE 1

Chemical composition of ilmenorutile and strüverite from Penikoja, Somero, SW Finland. Microprobe analyses.

\begin{tabular}{|c|c|c|c|c|}
\hline & \multirow{2}{*}{$\begin{array}{l}\text { Specimen } \\
\text { No. } 4561 \\
\text { Strüverite }\end{array}$} & \multicolumn{3}{|c|}{ Specimen No. 8810} \\
\hline & & Ilmenorutile & Ilmenorutile & Strüverite \\
\hline $\mathrm{Ta}_{2} \mathrm{O}_{5} \ldots \ldots$ & $21 \%$ & $19 \%$ & $10 \%$ & $22 \%$ \\
\hline $\mathrm{Nb}_{2} \mathrm{O}_{5} \ldots$ & 12 & 12 & $10^{/ 0}$ & 9 \\
\hline $\mathrm{FeO} \ldots$ & 8 & 13 & 8 & 14 \\
\hline $\mathrm{MnO}$. & n.d. & tr. & n.d. & tr. \\
\hline $\mathrm{TiO}_{2} \ldots$ & 55 & 53 & 66 & 48 \\
\hline $\mathrm{SnO}_{2} \ldots \ldots \ldots$ & 1 & 1 & 1 & 2 \\
\hline Total & 97 & 98 & 95 & 95 \\
\hline
\end{tabular}

Unit cell content based on $\mathrm{O}=4$.

\begin{tabular}{l|l|l|l|l}
\hline $\mathrm{Ta} \ldots \ldots \ldots$ & 0.19 & 0.17 & 0.09 & 0.21 \\
$\mathrm{Nb} \ldots \ldots \ldots$ & 0.18 & 0.18 & 0.14 & 0.14 \\
$\mathrm{Fe} \ldots \ldots \ldots$ & 0.22 & 0.36 & 0.21 & 0.42 \\
$\mathrm{Ti} \ldots \ldots \ldots$ & 1.40 & 1.35 & 1.59 & 1.30 \\
$\mathrm{Sn} \ldots \ldots \ldots \ldots$ & 0.013 & 0.013 & 0.012 & 0.028 \\
$\mathrm{Cation} \mathrm{sum}$ & 2.003 & 2.073 & 2.042 & 2.098 \\
(Fe, Mn) & $1.18 / 2$ & $2.06 / 2$ & $1.82 / 2$ & $2.4 / 2$ \\
$\mathrm{CNb}, \mathrm{Ta})$ & & & & \\
$\mathrm{Nb} / \mathrm{Ta} \ldots \ldots$ & 0.95 & 1.06 & 1.56 & 0.67
\end{tabular}

n.d.: not detected.

tr.: trace.

TABLE 2

Chemical composition of pseudo-ixiolite, columbite and cassiterite from Penikoja, Somero, SW Finland. Microprobe analyses.

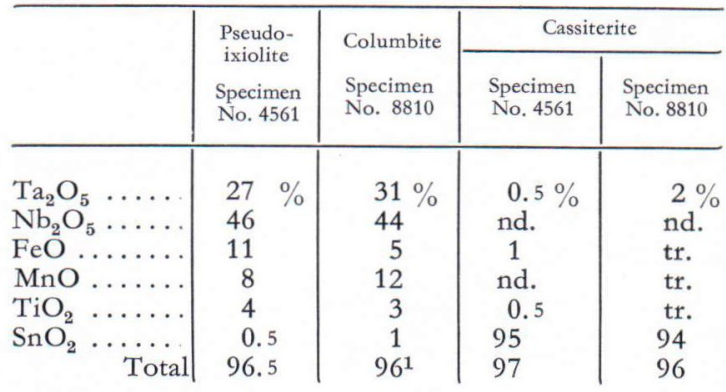

1) Average of two analyses.

n.d.: not detected.

tr.: trace.

erating voltage of $30 \mathrm{kV}$ was used in determining the Ti-content in ilmenorutile and strüverite. Analysing crystals were LiF and Mica. The characteristic lines used were 1 st order $K \alpha_{1}$-line for $\mathrm{Fe}, \mathrm{Mn}$ and $\mathrm{Ti}$ and 1 st order $L \alpha_{1}$-line for $\mathrm{Nb}$, $\mathrm{Sn}$ and $\mathrm{Ta}$. The following materials were used 
as standards: ilmenite (taken as $\mathrm{FeTiO}_{3}$ ), cassiterite (taken as 99.5 wt. \% $\mathrm{SnO}_{2}$ ), manganocolumbite (analysis published in: Vorma and Hoffrcn, 1965, p. 204, Anal. No. Rb 75/61) and synthetic TiO.

As is illustrated by Table 1, ilmenorutile and strüverite from the Penikoja pegmatite are characterised by high $\mathrm{TiO}_{2}, \mathrm{Ta}_{2} \mathrm{O}_{5}, \mathrm{Nb}_{2} \mathrm{O}_{5}$ and $\mathrm{FeO}$ contents with minor $\mathrm{SnO}_{2}$. The low content of $\mathrm{MnO}$ is remarkable because the surrounding minerals are rich in it (Table 2). An X-ray single crystal oscillation and precession photographs of strüverite, sample No. 4561, give the following monorutile unit cell dimensions (uncalibrated, Mo $K \alpha$-radiation): $a_{0}=4.62 \AA, c_{0}=2.99 \AA$ with $c_{\mathrm{o}}: a_{\mathrm{o}}=0.647$ (Vorma, 1965, oral commun.).

Table 2 summarises the chemical composition of pseudo-ixiolite, columbite and cassiterite found in the specimens studied. The pseudo-ixiolite and the columbite analysed are similar to each other in bulk composition. The cassiterite of specimen No. 8810 shows a fairly high tantalum content. The unit cell parameters of the pseudo-ixiolite No. 4561 have been given by Vorma (1965). The unit cell data for this mineral are summarised in Table 3. According to this table, (Fe, Mn, Ti, $\mathrm{Sn}):(\mathrm{Nb}, \mathrm{Ta})=1.36: 2$ with $\mathrm{Nb}: \mathrm{Ta}=2.84: 1$. Thus the analysis suggests the formula (Fe, Mn, $\mathrm{Ti}, \mathrm{Sn}, \mathrm{Nb}, \mathrm{Ta})_{4.06(7)} \mathrm{O}_{8}$ for this pseudo-ixiolite. The ratio $\mathrm{Nb}_{2} \mathrm{O}_{5}: \mathrm{Ta}_{2} \mathrm{O}_{5}$ (in weight percent) in the pseudo-ixiolite No. 4561 is $1.7: 1$, not $18: 1$ as was erroneously given by Vorma (1965, p.

TABLE 3

Unit cell of pseudo-ixiolite No. 4561 from Penikoja, Somero, SW Finland.

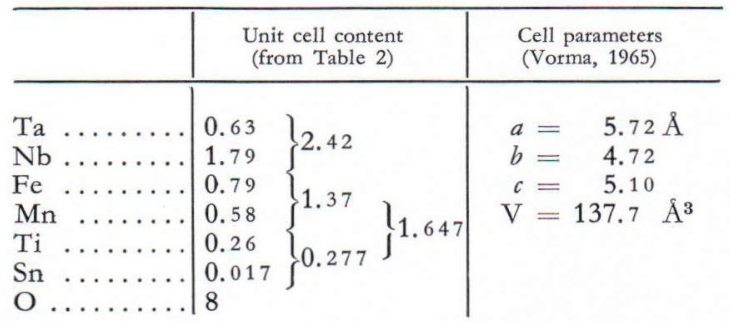

173). The error in the previously reported value of this ratio, determined by the $\mathrm{X}$-ray fluorescence method, is apparently due to the very small amount of material examined.

\section{Discussion}

Černý et al. (1964) presented a thourough review of the ilmenorutile-strüverite series and established diagrammatically the range of variation in the chemical composition of this series. Plotting the compositions of Table 1 in the diagrams reproduced by these authors (op. cit., Fig. 3 on p. 164 and Fig. 4 on p. 165) shows that the chemical composition of ilmenorutile and strüverite from Penikoja is in accordance with the general chemistry of these minerals. According to the classification scheme of Černý et al., the Penikoja specimens studied in this paper should be included in the section of sinhomogeneous specimens» which consist of a monorutile type mineral in association with an orthorhombic columbite (or pseudo-ixiolite) rich in niobium and manganese.

In distinguishing between ilmenorutile and strüverite, or between niobian rutile and tantalian rutile, the limiting ratio is considered to be $\mathrm{Nb} /$ $\mathrm{Ta}=1$. As has been remarked by Lima de Faria and Quadrado (1966), the value for the $a$ - parameter of the unit cell shows an increase along the sequence rutile - niobian rutile - tantalian rutile - tapiolite. Theoretically, the X-ray powder pattern could be used in estimating the $\mathrm{Nb} /$ Ta ratio in these minerals. In practice, however, more data correlating the $a$-parameter with the $\mathrm{Nb} / \mathrm{Ta}$ ratio are desirable. In the Penikoja specimen No. 8810 (Table 1) both ilmenorutile and strüverite are present, the ratio $\mathrm{Nb} / \mathrm{Ta}$ varying from 0.67 to 1.56 . Thus, a presence of columbite exsolutions does not necessarily indicate that the monorutile phase contains niobium in excess over tantalum (cf. Černý et al., p. 169). Because of the heterogeneous nature of specimen No. 8810 , no detailed X-ray study was made of the specimen. 
In specimen No. 8810 especially the $\mathrm{TiO}_{2}$, $\mathrm{Ta}_{2} \mathrm{O}_{5}$ and $\mathrm{Nb}_{2} \mathrm{O}_{5}$ contents vary greatly. The differences in composition do not affect the optical properties. Therefore, domains of differing compositions cannot be distinguished from each other under the microscope. When the specimen surface is subjected to the electron beam of a microprobe, the image which is monitored by the backscattered electrons distinctly shows the variations in composition. The electron backscattering power of the sample surface varies greatly as a function of the $\mathrm{TiO}_{2}, \mathrm{Ta}_{2} \mathrm{O}_{5}$ and
$\mathrm{Nb}_{2} \mathrm{O}_{5}$ contents. Thus a qualitative examination of this specimen proved the $\mathrm{Nb}$, Ta-rich rutile phase to be very heterogeneous indeed. Once more, this fact reflects the varying conditions of crystallisation in the Penikoja pegmatite area in Somero, also shown by the common occurrence of disordered columbite.

Acknowledgements - The author wishes to express his gratitude to Dr. Atso Vorma for placing the samples at his disposal as also for the many critical discussions and to Mr. Erkki Halme for the photographs.

\section{REFERENCES}

Č́nnÝ, P., Č ECH, F. and Povondra, P. (1964) Rewiew of ilmenorutile-strüverite minerals. N. Jb. Miner. Abh. (2), 101, 142-172.

LIMA DE FARIA, J. and QUAdRAdo, R. (1966) Ilmenorutile and struverite from Nampoça, Alto Ligonha, Mozambique. Garcia de Orta, 14, 305-310.

Vorma, Atso (1965) Notes on columbite and tapiolite from the pegmatite area of Tammela and Somero in SW Finland. Bull. Comm. Géol. Finlande, 218, 169176.
Vorma, Atso and Hoffrén, VÄINÖ (1965) On adelpholite and its relation to the minerals of the yttrotantalitesamarskite series. Bull. Comm. Géol. Finlande, 218, $201-214$.

Vorma, Atso and Sirvola, JаAкко (1967) Sukulaite $\mathrm{Ta}_{2} \mathrm{Sn}_{2} \mathrm{O}_{7}$ - and wodginite as inclusions in cassiterite in the granite pegmatite in Sukula, Tammela in SW Finland. Bull. Comm. Géol. Finlande, 229, 173-187.

Manuscript received, May 27, 1969. 